\title{
Developing HRIS for Predictive Attrition and Retention management of Indian IT Engineers- using ANN, ANOVA and Smart PLS
}

\author{
Shivinder Nijjer, Jaskirat Singh, Sahil Raj
}

\begin{abstract}
Growth of IT sector in India (Heeks, 2015) is phenomenal, however, employee turnover has been a persistent issue in IT sector (Yiu \& Saner, 2008). Voluntarily turnover among employees has been attributed to dissatisfaction with organizational factors and individual characteristics (Elkjaer \& Filmer, 2015). Therefore, this research examines how to retain employees in IT firms, by focusing on the Job attitudes, theory of individual differences and theory of planned behaviour. It also explores which individual characteristics contribute to employee turnover intent, as a consequence of their negative job attitudes. The techniques of Artificial Neural Networks, Two-way ANOVA and PLS testing have been utilised. The analysis confirms the proposition that individual differences have an effect on job attitudes, which ultimately affect the turnover intention.
\end{abstract}

Index terms: Predictive Analytics, ANN, HRM, Attrition, Retention, IT industry, Software Engineers

\section{INTRODUCTION}

Growth of IT sector in India (Heeks, 2015) is phenomenal, and its contribution India GDP is the highest (FE Bureau 2018). However employee turnover has been a persistent issues in IT sector (Yiu \& Saner, 2008), prevalent across all categories of employees and increasing with the skill level of the employees (Cho \& Lewis, 2012). Resource-based view (RBV) suggests (Holland, Sheehan, \& Cieri, 2007) that a firm gains highest competitive advantage through its human resources (Ostroff \& Bowen, 2016), highlighting the importance of retention. Therefore PO fit can play a significant role in retaining employees in high turnover jobs (McCulloch \& Turban, 2007). Issues of retention and its management vary significantly among industry and organisations (Sheridan, 1992).

Therefore, this study examines how to retain employees in IT firms, by focusing on the 'work environment congruence' and 'value congruence' approach to PersonOrganisation fit. In addition, based on the theory of individual differences and theory of planned behaviour, the study also attempts to explore which individual characteristics contribute to employee turnover intent, as a consequence of their negative job attitudes. The techniques of Artificial Neural Networks, Two-way ANOVA and PLS testing has been utilised to uncover the retention mix of

\section{Revised Manuscript Received on June 15, 2019.}

Dr. Shivinder Nijjer, School of Management Studies, Punjabi University, Patiala, India.

Jaskirat Singh, Chandigarh Business School of Administration, Chandigarh Group of Colleges, Landran, India.

Dr. Sahil Raj, School of Management Studies, Punjabi University, Patiala, India. benefits and mine out the individual differences which contribute to employee turnover. Further these characteristics can be used to build a predictive attrition indicator system.

\section{A. Objectives of the Study}

1. To build predictive attrition indicator system for different stages of employment of software engineers in tier 1 Indian IT firms

a. This objective is achieved using application of PLS (partial least squares) modelling of the research problem and then ANN (Artificial Neural Networks) to discern the individual traits most predictive of attrition at a particular stage of employment.

2. To propose a retention model for suggesting variation in retention mix of benefits offered to software engineers by their stage of employment

a. This objective is achieved using application of Two-Way ANOVA suggesting how retention benefits should vary by stage of employment and gender of the engineer.

\section{LITERATURE REVIEW}

India is the most sought after destination for outsourcing of IT services (Presbitero, Roxas, \& Chadee, 2016), however, this sector suffers from high turnover rates. Indian IT industry is in dire need of shift in focus from recruitment towards retention (Kumar \& Arora, 2012). Meaningful work and organisational practices that increase employee motivation intrinsically discourage turnover (Cho \& Lewis, 2012) (Kim, 2005). Studies acknowledge that HRM practices which fit with the value system of the employee, such as competitive remuneration, training and development, etc., positively affect an employee's job attitudes, thereby increasing their rate of retention (Richter \& Schrader, 2016) (Cascio, 2014).

In addition to managing retention through HRM practices, it can also be managed by addressing and understanding the root cause of the problem of turnover. One approach of turnover management is by managing differences in individual traits as these lead to difference in their job attitudes (Cooper 2010) (Judge and Bono 2001), leading to turnover. Theory of Planned Behavior (TPB) (Ajzen 1991), rooted in the Theory of Reasoned Action (TRA) (Ajzen and Fishbein 1980) explains how dispositional attitudes such as

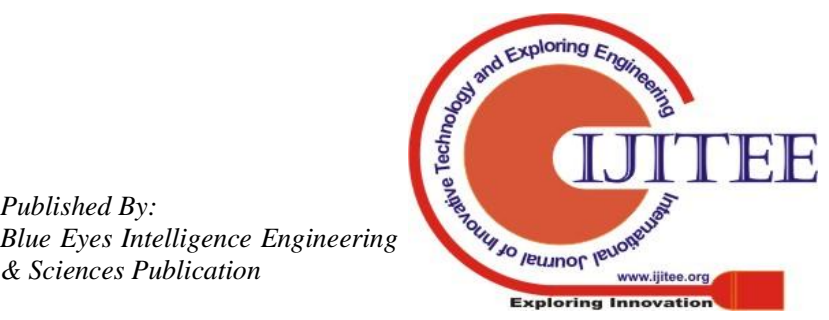




\section{Developing HRIS for Predictive Attrition and Retention Management of Indian IT Engineers- Using}

ANN, ANOVA and SmartPLS

intention lead to actual behaviour. Job attitudes - Job Satisfaction, and perceived Person Organisation (PO) fit have been seen to be significant predictors of turnover (Breukelen, Vlist and Steensma 2004) (Gaur, Goswami and Quazi 2014) (vanVianen, DePater, \& Dijk, 2007). IT firms now hire employees for their desirable traits (Maurer 2015), such as intellectual humility (Anderson 2014), proactive personality and adaptability and collaboration (Park 2011). Therefore, the premise of this study is that retention of software engineers can be managed through 1. HRM practices or retention mix of benefits, and 2 . Through investigation of their job attitudes which are a function of an employee's individual traits such as personality, intellectual humility, self-efficacy and self-esteem; and therefore can aid in prediction of turnover and hence aid in retention.

\section{HYPOTHESIS DEVELOPMENT AND RESEARCH FRAMEWORK}

\section{A. Objective 1}

To predict turnover in organisations, we use intention to quit as the predictor variable and Job Satisfaction, and perceived Person Organisation (PO) fit as the job attitudes. The individual differences used for the study are SelfEsteem, Self-Efficacy, Intellectual Humility, Resilience and Personality. Following from TPB, the research framework (Figure 1) is to verify the proposition whether 'individual differences lead to varying job attitudes which further lead to turnover intent' is satisfied, through application of SmartPLS? Thereafter, ANN would be applied to categorize the individual traits predictive of intent to stay and quit, which can be used to build a predictive model for attrition and selection, aiding in retention of the engineers. Selfesteem impacts an individual's life attitude and hence their behavioral adaptation at the workplace and is therefore, a strong predictor of Job Satisfaction and PO fit (Judge and Bono 2001) (Judge and Kammeyer-Mueller 2012). Resilience by enhancing individual adaptability increases their Job Satisfaction and lowers turnover intention (Youssef and Luthans 2007), while through depersonalised processing of information, induces a better PO fit (Cheung, Tang and Tang 2011). Personality and its five-factor dimensions are a key measure of individual differences, significantly contributing to Job Satisfaction and PO fit (Judge and Kammeyer-Mueller 2012). Intellectual humility builds an individual's social skills and resilience, causing enhanced job satisfaction (Hook, et al., 2015).

Therefore, it is hypothesized that (Fig. 1):

$\mathrm{H1}, 3,5,8,9,11,13$, and 17 - There is a significant relation between Self-Esteem, Resilience, Emotional Stability, Extraversion, Agreeableness, Conscientiousness, and Intellectual Humility with Person Organisation Fit.

H 2, 4, 6, 8, 10, 12, 13 and 18 - There is a significant relation between Self-Esteem, Resilience, Emotional Stability, Extraversion, Agreeableness, Conscientiousness, and Intellectual Humility with Job Satisfaction.

When individuals perceive a high degree of organizational fit, it leads to better work outcomes such as satisfaction and tenure (Ehrhart and Ziegert 2005), while Job satisfaction lowers an individual's turnover intention (Trimble 2006). The most widely used antecedents of voluntary turnover are job satisfaction, organisational commitment, and intention to quit (Shaw 2010).

H14 and H15 - PO fit is significantly related with Job Satisfaction and Turnover Intention.

H16 - Job Satisfaction has a significant negative relation with Turnover Intention.

\section{B. Objective 2}

The research model has been depicted in Figure 1.

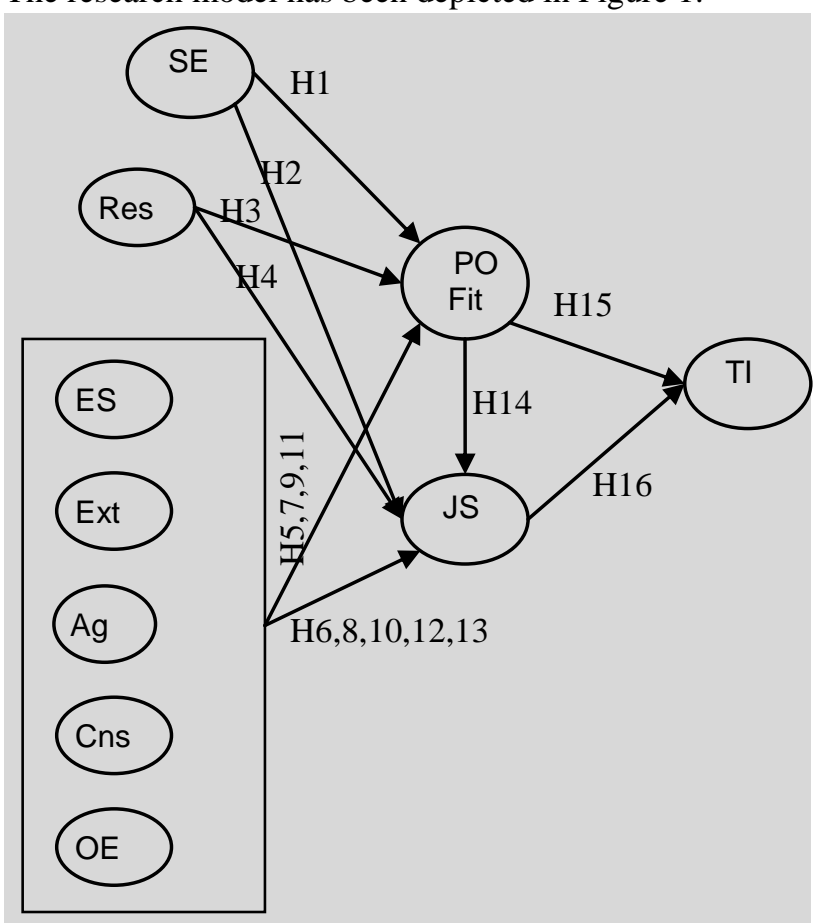

Fig 1. Research Model for PLS Testing

The abbreviations used in the diagram are SE - Self Esteem, Res - Resilience, ES - Emotional Stability, Ext Extraversion, Ag - Agreeableness, Cns Conscientiousness, OE - Openness to Experiences, IH Intellectual Humility, JS - Job Satisfaction and TI Turnover Intention.

The benefits offered to employees currently in tier 1 Indian IT firms were garnered through literature review, interviews and brainstorming with subject experts. A semantic analysis of the garnered factors was carried (PobaNzaou, Lemeiux, Beaupre, \& Uwizeyemungu, 2016) to create a total of 8 categories of retention mix of benefits Employee benefits, Family friendly practices, Work-life balance practices, Company Identification, Self Enlightenment and other factors are 'Remuneration', 'Training and Development', and 'Recognition and Job Security' (Yamamoto, 2011) (Guchait \& Cho, 2010) (Fairris, 2004) (Batt \& Valcour, 2003). Although firms offer similar benefits to all employees, the authors posit that the preference of benefits will differ by each designation (Nishii, Lepak, \& Schneider, 2008), organizations and organizational settings (Fletcher, Alfes, \& Robinson, 2016) and hence 
retention too should be targeted based on the

stage of employment (Presbitero, Roxas, \& Chadee, 2016). Therefore, we hypothesize the following:

H1 to H8: Perception of - Remuneration, Training and Development, Work Life balance practices, Family Friendly practices, Self Enlightenment, Recognition and Job Security, Employee Benefits, Company Identification - as a retention factor, respectively, significantly varies with designation and organization.

\section{RESEARCH METHODOLOGY}

\section{A. Objective 1}

A survey was developed using Google forms to assess individual differences and job attitudes of the software engineers in tier-1 IT firms (NASSCOM 2015) in India. Convenience and snowball sampling were used over a period of three months and 581 usable responses were received. Hypothesis testing was carried using PLS (partial least squares) modelling technique using SmartPLS software.

\section{ARTIFICIAL NEURAL NETWORKS}

Artificial neural networks (ANN) are used to model any type of complex functional relationships. ANN has three layers -input, hidden and output layer, and the output is computed as the weighted average of the inputs. The observed data is used to train the network and ANN learns the functional relationship by adjusting weights for each input in multiple iterations, till least error stage is reached, provided in the algorithm (Xuming, Mingyuan, Qian, Li, Zhongyi, \& Lin, 2016). ANN in SQL Server 2012 uses multilayer perceptron and conjugate gradient algorithm to model functional relationships (Gunther \& Fritsch, 2010).

\section{A. Construction of SQL Server 2012 ANN mining model}

The structure of the neural network model used in this study is as shown in figure 2 .

The survey data initially stored in excel sheet was exported to a SQL Server 2012 table, using SQL Server 2012 Data Tools (SSDT), Integration Services project. ANN was applied using Analysis Services project in SSDT, using the table as the data source. SQL Server 2012 mining model output contains the key influencers for a given dependent variable, a 'Score' depicting overall importance of the variable towards prediction, 'Probability' of occurrence for different output states, and a 'Lift score' depicting its relative importance.

\section{A. Objective 2}

Another survey gauged the preferred mix of benefits by software engineers on a five-point Likert scale. The two categories of organisations in the study are - Indian origin firms and Outsiders. The sampling technique used is stratified sampling, convenience and snowball sampling, with the size of each stratum being 100 and stratification variables being Designation and Organisation. Two-Way
ANOVA was applied to assess the variation in preference of retention mix of benefits.

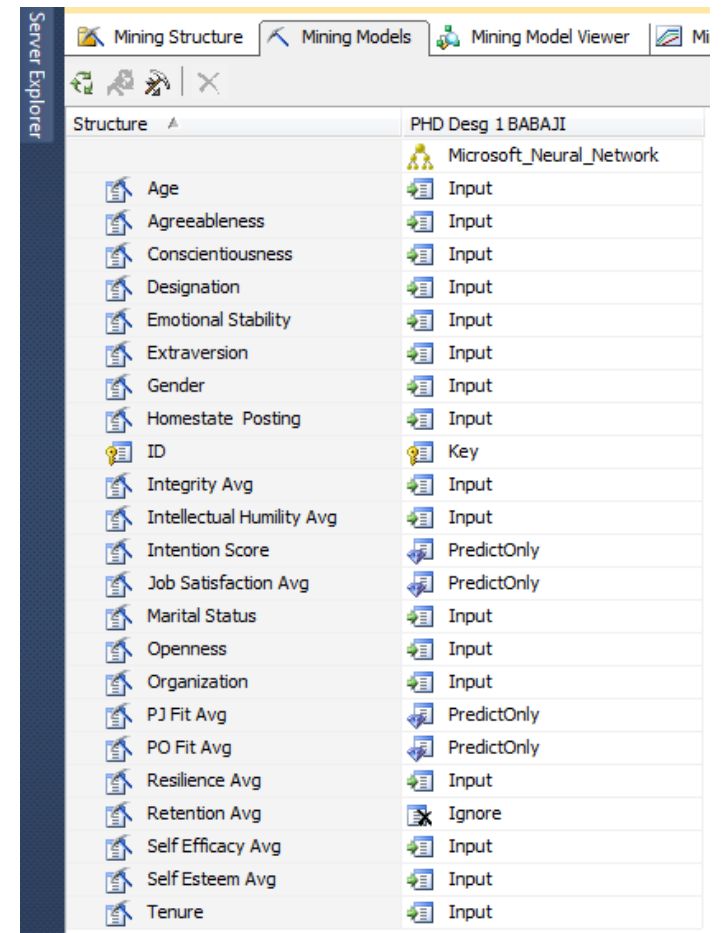

Fig 2. Structure of ANN mining model used in the study

\section{A. Objective 1}

SmartPLS output revealed that $57.4 \%$ of the variance in the target variable 'Turnover Intention' was explained through the job attitudes, while individual characteristics explain $23 \%$ and $51.3 \%$ variance in PO Fit and Job Satisfaction, respectively.

ANN output reveals the factors useful to build a predictive attrition model, which imply low job satisfaction, low PO fit and high turnover intent, and are arranged by different stages of employment of the respondents viz. Level 1, 2 and 3 .

Of higher concern for turnover intent at the first level of software engineers are: Agreeableness, Openness to Experience, Extraversion, Marital Status and tenure with the firm, each of which have been found to have reverse relation with intention to quit, consistent with previous studies (Judge and Kammeyer-Mueller 2012) (Lebreton, et al. 2004).

Tenure is also negatively related with turnover intent, and positively related with Job satisfaction and PO fit; while Marital status increases financial obligations which lowers one's turnover intentions (Emiroglu, Akova, \& Tanriverdi, 2015).

At level 2, the factors which have the highest and negative impact on intention quit are Extraversion, Resilience, Intellectual humility, Self-esteem and Tenure. Resilient individuals can deal with adversities and still be satisfied with their jobs and have lower turnover intent.

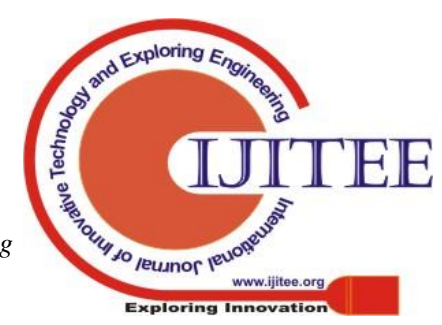




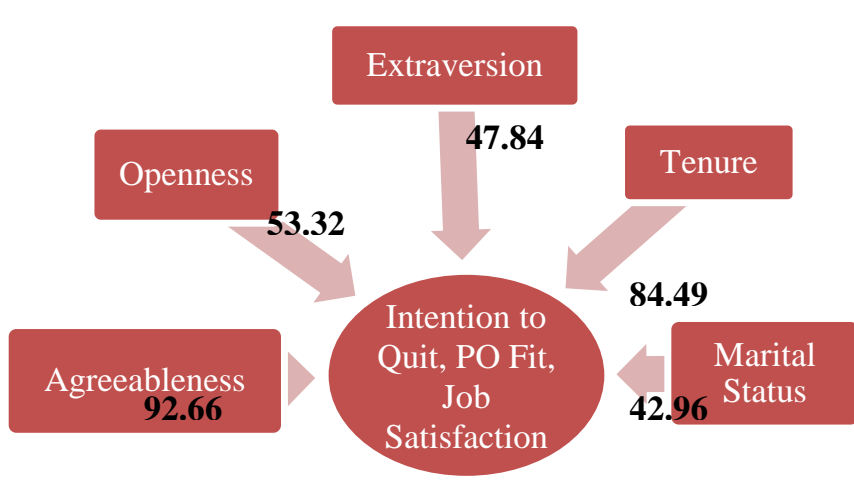

Fig 3. Model depicting predictors for turnover for level 1 (from ANN output

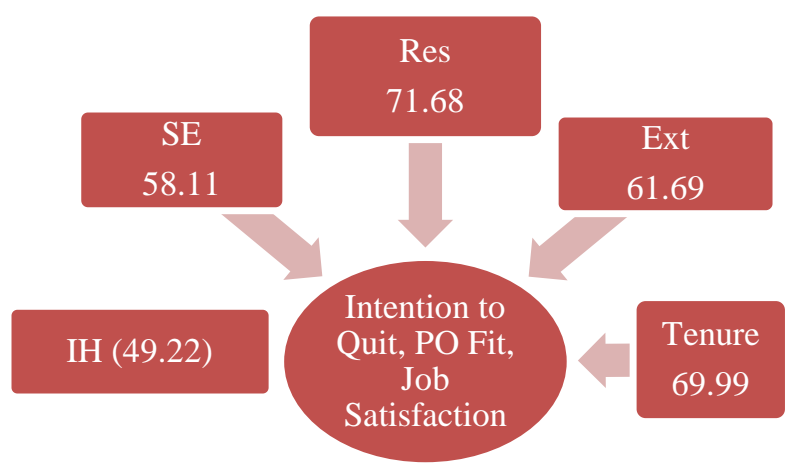

Fig 4. Predictors for turnover for level 2 (from ANN)

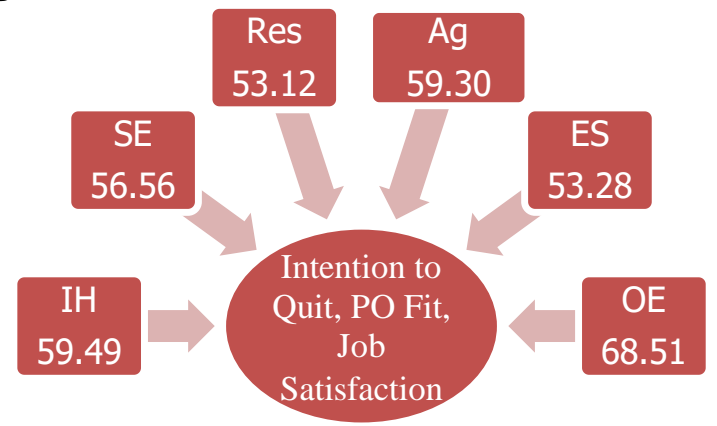

Fig 5. Predictors for turnover for level 3 (from ANN)

At level 2 in IT industries, additional set of job duties, leading and guiding subordinates requires individuals to be intellectually humble, which can otherwise lead to increase in intention to quit (Griffin, 2017).

At level 3, Resilience, Intellectual humility and selfesteem strongly predict turnover intent. In IT sector, career growth requires individual to possess intellectual humility and resilience. Additionally, faith in one's abilities increases job satisfaction and lowers turnover intention.

\section{B. Objective 2}

The most attractive factors (Figure 6) for retaining level 1 employee are training and development, recognition and job security, company identification, work-life balance practices, employee benefits, and family-friendly practices; the reasons being - reputation and size of the firm, compensation and benefits, need for security, educational support and supervisor support (Cascio W. F., 2014).

At level 2 in IT sector, Remuneration, Training and Development, Work life balance practices, family friendly practices, and Company Identification; since here they are more interested in enhancing their skills and abilities for career development and better compensation.

\begin{tabular}{|c|c|c|c|c|c|}
\hline & & & & & \\
\hline 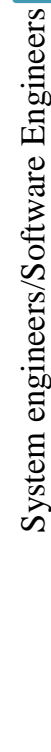 & $\begin{array}{l}\text { - Training } \\
\text { and } \\
\text { Develop } \\
\text { ment } \\
\text { - Company } \\
\text { Identifica } \\
\text { tion } \\
\text { - Work } \\
\text { Life } \\
\text { Balance } \\
\text { Practices } \\
\text { - Recogniti } \\
\text { on and } \\
\text { Job } \\
\text { Security } \\
\text { - Employee } \\
\text { benefits } \\
\text { - Family } \\
\text { friendly } \\
\text { practices }\end{array}$ & 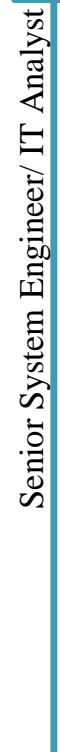 & $\begin{array}{l}\cdot \text { Remuner } \\
\text { ation } \\
\text { - Training } \\
\text { and } \\
\text { Develop } \\
\text { ment } \\
\text { - Work } \\
\text { Life } \\
\text { Balance } \\
\text { Practices } \\
\text { - Family } \\
\text { Friendly } \\
\text { Practices } \\
\text { - Company } \\
\text { Identifica } \\
\text { tion }\end{array}$ & 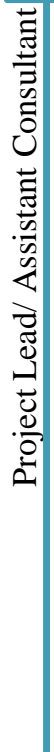 & $\begin{array}{l}\cdot \text { Remuner } \\
\text { ation } \\
\text { - Company } \\
\text { Identifica } \\
\text { tion } \\
\text { - Self- } \\
\text { Enlighten } \\
\text { ment } \\
\text { - Recogniti } \\
\text { on and } \\
\text { Job } \\
\text { Security } \\
\text { - Family } \\
\text { friendly } \\
\text { practices } \\
\text { - Work } \\
\text { Life } \\
\text { Balance } \\
\text { practices }\end{array}$ \\
\hline
\end{tabular}

\section{Figure 6. Model depicting retention mix of benefits preferred by each designation}

At level 3 in IT sector, Remuneration, Company Identification, Self-Enlightenment, Recognition and job security, Family friendly practices, and Work-life balance practices are the most important factors retention. Higher responsibilities reinforce the need for a mentor, empowerment and expression of voice. Also, company size and image matter a lot, causing probably job hopping (Hamori, 2010).

\section{CONCLUSION}

The study confirms the proposition that Individual characteristics determine their job attitudes - PO fit and Job Satisfaction and further intention to quit. Therefore, periodic monitoring of job attitudes can aid in timely prediction of their intention to quit. Complexity of technologies and lack of expertise in any given field of an IT professional adds to his burden of proving competence repeatedly which requires an individual to be resilient. Further intellectual humility asserts the quest for knowledge and love of learning and sociability. Cheerful personality reinforces resilience and promoted sustainability. Additionally, the study also worked on the theory of work adjustment and identified the retention mix of benefits offered by different IT firms and how the perception of preference by different designation varies in the firms under study. The findings of the study would aid the IT organisations to develop retention strategies targeted at different designations in the firms.

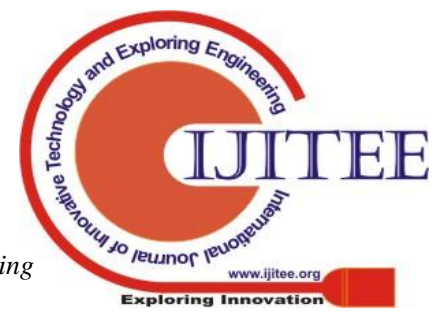




\section{REFERENCES}

1. 1 Heeks, R. (2015, April 28). Indian IT/Software Statistics: 1980 2015 time series data. Retrieved from ICT BLOG https://ict4blog.wordpress.com/2015/04/28/indian-itsoftware-sectorstatistics-1980-2015-time-series-data/

2. 2 Holland, P., Sheehan, C., \& Cieri, H. D. (2007). Attracting and retaining talent: exploring human resources development trends in Australia. Human Resource Development International , 247-262.

3. 3 Ostroff, C., \& Bowen, D. E. (2016). Reflections on the 2014 decade award: Is there strength in the construct of HR system strength?. Academy of Management Review, 196-214.

4. 4 Bellou, V., Chaniotakis, I., Kehagias, I., \& Rigopoulou, I. (2013) Employer Brand of Choice: an employee perspective. Journal of Business Economics and Management, 1201-1215.

5. 5 McCulloch, M. C., \& Turban, D. B. (2007). Using PersonOrganization Fit to select employees for high turnover jobs. International Journal of Selection and Assessment, 63-71.

6. 6 Sheridan, J. E. (1992). Organisational Culture and Employee Retention. The Academy of Management Journal , 1036-1056.

7. 7 Presbitero, A., Roxas, B., \& Chadee, D. (2016). Looking beyond HRM practices in enhancing employee retention in BPOs: focus on employee-organisation value fit. The International Journal of Human Resource Management , 635-652.

8. 8 Richter, A., \& Schrader, S. (2016). Financial participation and recruitment and retention. The International Journal of Human resource management .

9. 9 Cascio, W. F. (2014). Leveraging employer branding, performance management and human resource development to enhance employee retention . Human Resource Development International , 121-128.

10. 10 Breukelen, Wim Van, Rene Van Der Vlist, and Herman Steensma. "Voluntary employee turnover: combining variables from the 'traditional' turnover literature with the theory of planned behavior." Journal of Organisational Behavior, 2004: 893-914.

11. 11 Hoffman, B. J., \& Woehr, D. J. (2006). A quantitative review of the relationship between person-organisation fit and behavioural outcomes. Journal of Vocational Behavior, 389-399.

12. 12 Cooper, Colin (2010). Individual Differences and Personality, Oxon, NY: Routledge, Taylor and Francis Group.

13. 13 Judge, Timothy A., and John D. Kammeyer-Mueller. "Job Attitudes." Annual Review of Psychology, 2012: 341-367.

14. 14 Judge, Timothy A., and Joyce E. Bono. "Relationship of Core Self-Evaluations Traits-Self- Esteem, Generalized Self-Efficacy, Locus of Control, and Emotional Stability-With Job Satisfaction and Job Performance: A Meta-Analysis." Journal of Applied Psychology, 2001: 80-92.

15. 15 FE Bureau (2018), - India IT-BPM Sector Revenue Expected to Touch $\$ 350$ bn by 2025, Says IT Minister,\| Financial Express July 11,2018 , accessed on December 28 https://www.financialexpress.com/industry/india-it-bpm-sectorrevenue-expected-to-touchminister/1239509.

16. 16 Yiu, L., \& Saner, R. (2008). Indian Employee turnover report Confederation of Indian Industry.

17. 17 Cho, Y. J., \& Lewis, G. B. (2012). Turnover Intention and Turnover Behavior: Implications for Retaining federal Employees. Review of Public Personnel Administration , 4-23.

18. 18 Kumar, R., \& Arora, R. (2012). Determinants of talent retention in BPO industry. Indian Journal of Industrial Relations , 259-273.

19. $19 \mathrm{Kim}, \mathrm{S}$. (2005). Factors affecting state government information technology employee turnover intentions. American Review of Public Administration , 137-156.

20. 20 Moynihan, D. P., \& Landuyt, N. (2008). Explaining turnove intention in state government:Examining the roles of gender, life cycle, and loyalty. Review of Public Personnel Administration , 120143.

21. 21 Ajzen, I., and M. Fishbein. Understanding attitudes and predicting social behavior.Engelwood Cliffs, NJ: Prentice-Hall, 1980

22. 22 Ajzen, Icek. "The Theory of Planned Behavior." Organisational Behavior and Human Decision Processes, 1991: 179-211.

23. 23 Gaur, Sanjaya S., Manish Goswami, and Ali Quazi. "Does relational paradigm lead to staff commitment: evidence from Indian call centres." Journal for Global Business Advancement, 2014: 287302.

24. 24 Maurer, Roy. "How to begin hiring veterans?" Societ for Human Resource Management. July 2015. google-looks-for-in-new-hires.
25. 25 Park, Ben. "How TO: land a job at Facebook." Mashable India April 2011. http://mashable.com/2011/04/03/facebook-jobs-2/.

26. 26 Anderson, Mike. "5 traits Google looks for in new hires." Code Fellows. March 2014. https://www.codefellows.org/blog/5-traits-

27. 27 Youssef, Carolyn M., and Fred Luthans (2007). "Positive Organizational Behavior in the Workplace: The Impact of Hope, Optimism and Resilience." Journal of Management, 774-800.

28. 28 Wanberg, Connie R., and Joseph T. Banas (2000). "Predictors and Outcomes of Openness to Changes in a Reorganising Workplace." Journal of Applied Psychology, 132-142.

29. 29 Xuming, Y., Mingyuan, Q., Qian, L., Li, C., Zhongyi, Y., \& Lin, Y. (2016). Information integration research on cumulative effect of 'Siqi, Wuwei, and Guijing' in traditional chinese medicine. Journal of Traditional Chinese Medicine, 538-546.

30. 30 Yamamoto, H. (2011). The relationship between employee benefit managament and employee retention. The International Journal of Human Resource Management, 3550-3564.

31. 31 Cheung, Francis, Catherine So-Kum Tang, and Shuwen Tang. "Psychological Capital as a Moderator Between Emotional Labor, Burnout, and Job Satisfaction Among School Teachers in China." International journal of stress management, 2011: 348-371.

32. 32 Griffin, A. (2017, March 17). 'Intellectual humility' could be key to becoming a better person, scientists say. Retrieved from Independent:

http://www.independent.co.uk/news/science/intellectual-humilityduke-university-study-how-to-be-a-better-person-personalitycharacteristic-a7636011.html

33. 33 Guchait, P., \& Cho, S. (2010). The impact of human resource management practices on intention to leave of employees in the service industry in India: the mediating role of organizational commitment. The International Journal of Human Resource Management, 1228-1247.

34. 34 Gunther, F., \& Fritsch, S. (2010). neuralnet: Training of neural networks. The R Journal , 30-38.

35. 35 Hamori, M. (2010, July-August). Managing Yourself: JobHopping to the Top and Other Career Fallacies. Retrieved from Harvard Business Review: https://hbr.org/2010/07/managingyourself-job-hopping-to-the-top-and-other-career-fallacies

36. 36 Hook, J. N., Davis, D. E., Tongeren, D. R., Hill, P. C., Humility and forgiveness of religious leaders. The Journal of Positive Psychology: Dedicated to furthering research and promoting good practice.

37. 37 Fletcher, L., Alfes, K., \& Robinson, D. (2016). The relationshipbetween perceived training and development and employee retention: the mediating role of work attitudes. The International Journal of Human Resource Management

38. 38 Fairris, D. (2004). Internal Labor Markets and Worker Quits. Industrial Relations , 573-594.

39. 39 Emiroglu, B. D., Akova, O., \& Tanriverdi, H. (2015). The relationship between turnover intention and demograohic factors in hotel business: A study at five star hotels in Istanbul. Procedia-Social and Behaviorial Sciences, 385-397.

40. 40 Ehrhart, Karen Holcombe, and Jonathan C. Ziegert. "Why are individuals attracted to organisations?" Journal of Management, 2005: 901-919.

41. 41 Trimble, Douglas E. "Organizational Commitment, Job Satisfaction, and Turnover Intention of Missionaries." Journal of Psychology and Theology, 2006: 349-360.

42. '42 Shaw, Jason D. "Job Satisfaction and Turnover Intentions: The Moderating Role of Positive Affect." The Journal of Social Psychology, 2010: 242-244.

43. 43 Cascio, W. F. (2014). Leveraging employer branding, performance management and human resource development to enhance employee retention . Human Resource Development International, 121-128.

44. 44 Batt, R., \& Valcour, P. (2003). Human Resources Practices as Predictors of Work-Family Outcomes and Employee Turnover. Industrial Relations , 189-220.

45. 45 Nishii, L. H., Lepak, D. P., \& Schneider, B. (2008). Employee attributions of the "why" of hr practices: Their effects on employee attitudes and behaviors, and customer satisfaction. Personnel Psychology, 503-545.

46. 46 NASSCOM. "Industry Rankings." NASSCOM. 2015. www.nasscom.in/industry- 
Developing HRIS for Predictive Attrition and Retention Management of Indian IT Engineers- Using ANN, ANOVA and SmartPLS

ranking\&grqid=Olc_lak\&hl=en-IN .

\section{AUTHORS PROFILE}

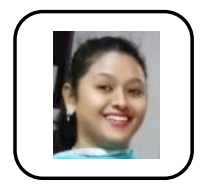

Dr. Shivinder Nijjer is a doctorate in Human Resources Management. Her areas of expertise include Artificial Neural Networks, Information Systems and Business Analytics. She is a contributing author for the book on Management Information Systems by Dr. Sahil Raj, Pearson Publications. She has more than 3 years of teaching experience in the field of IT and Analytics, and working knowledge of SQL Server 2012, SPSS, SmartPLS and MS Excel. She has also worked as a Software Engineer in Infosys Technologies Limited for a period of two years. Her other educational qualifications include Bachelor of Technology in Electronics and Communication Engineering and Masters of Business Administration in Human Resource Management and Marketing Management. She has also published articles in leading journals in the field of Business Management.

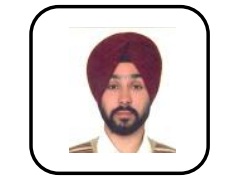

Jaskirat Singh is working as an Assistant Professor in the department of Chandigarh Business School of Administration (CBSA), Chandigarh Group of Colleges (CGC), Landran, India. He has accomplished his Master of Business Administration degree from Guru Nanak Dev University, Amritsar. He has also done Master of Economics and Post Graduate Diploma in Computer Application from Punjabi University, Patiala and Higher Diploma in Cooperative Management from Regional Institute of Cooperative Management, Chandigarh. He is doing the research in the field of sports marketing, particularly concentrated on the marketing practices used by national and multi-national organizations in the Indian Premier League. He has published articles in leading journals in the field of business and sport Management. $\mathrm{He}$ teaches in the field of strategic and marketing research.

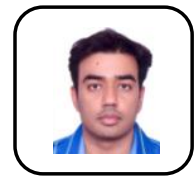

Dr. Sahil Raj has more than a decade of teaching experience in the field of Information Systems and Business Analytics. He has authored four books on the subjects of Information Systems and Analytics with leading publishers Pearson and Cengage. He has been a Visiting Faculty at Humber College, Canada. He has also contributed in global editions of many books on Pearson Publications. He has published quality articles in leading journals and is now guiding doctoral research projects in the area of Artificial Neural Networks, Decision Trees, Big Data analytics and Information Systems. 